\section{Tacrine and lecithin in Alzheimer's disease}

\section{Tacrine is safe and effective}

EDITOR,-As two of the authors of a paper that reports the efficacy and safety of $160 \mathrm{mg}$ of tacrine (base) used over 30 weeks, ${ }^{1}$ we believe that the conclusions of Maltby $e t a{ }^{2}$ are inappropriate with regard to the use of tacrine for the treatment of Alzheimer's disease for the following reasons.

Firstly, the number of patients treated with tacrine who completed the entire 36 weeks of treatment was exceedingly low (14 patients). It is surprising that the authors are willing to make such negative comments about the drug, given the results of our study and another recently published, well controlled, multicentre study, ${ }^{3}$ the combined results of which are based on over 500 patients who completed the protocols.

Secondly, the maximum dose of tacrine used in Maltby et als study was $100 \mathrm{mg}$ (hydrochloride salt, equivalent to $80 \mathrm{mg}$ base), with an average dose of $77.3 \mathrm{mg}$. The efficacy of tacrine begins to become apparent at these dosage levels, and the benefit of the drug is greater at doses of 120 and 160 $\mathrm{mg}$ (base). As opposed to the contention of the authors, a dose of $160 \mathrm{mg}$ of tacrine is well tolerated by many patients, and it is safe.

Thirdly, in Maltby et als study, the group treated with tacrine had an average duration of illness of 5.4 years, and the placebo group had an average duration of illness of 2.5 years. One would expect the viability of the brain's intrinsic cholinergic system to become increasingly compromised as Alzheimer's disease progresses, and therefore the response to tacrine to become less. Thus, to compare a tacrine group with a placebo group that has a duration of illness of less than half is inappropriate.

Fourthly, the liver dysfunction observed by the authors during the course of their study is similar to our own experience in that increases in ALT elevations are entirely reversible when tacrine is stopped. In addition, the liver dysfunction indicated by ALT elevations was always asymptomatic in other recently completed studies. ${ }^{4}$

In summary, we believe that tacrine is a safe and effective drug for the treatment of Alzheimer's disease. We hope that physicians do not make decisions concerning their use of the drug on the basic of the results and conclusions of Maltby $e t a l$ s study. Much better data ${ }^{134}$ are available on which to make an informed decision about the use of tacrine.

WILLIAM W PENDLEBURY University of Vermont Burlington, VT 05405 USA

Williams College, Williamstown MA

USA

I Knapp MJ, Knopman DS, Solomon PR, Pendlebury WW, Davis CS, Gracon SI. A 30-week randomized controlled trial of high-dose tacrine in patients with Alzheimer's disease. JAMA 1992;271:985-91.

2 Maltby N, Broe GA, Creasey H, Jom AF, Christensen WSB. Efficacy of tacrine and lecithin in mild to moderate Alzheimer's disease: double blind trial. BMY 1994;308:879-83. (2 April.)

3 Farlow M, Gracon SI, Hershey LA, Lewis KW, Sadowsky CH, Dolan-Ureno J. A controlled trial of tacrine in Alzheimer's disease. FAMA 1992;268:2523-9.

4 Watkins PB, Zimmerman HJ, Knapp MJ, Gracon SI, Lewis KW. Hepatotoxic effects of tacrine administration in patients with Alzheimer's disease. YAMA 1994;271:991-8.
Letters should be no more than $\mathbf{4 0 0}$ words long, should contain a maximum of five references including one to the $B M \mathcal{F}$ article to which they refer, and must be typed with double spacing. All authors need to sign the letter and provide their current appointment and address. Please enclose a stamped addressed envelope if you require an acknowledgment. First reports of original research are not published in the letters section.

\section{Patient heterogeneity explains varied response}

EDrToR,-I fear that my off the cuff remarks in Berlin may have mislead Jane Byrne and Tom Arie ${ }^{1}$ into thinking that three tetrahydroaminoacridine (tacrine) responders who came to necropsy suffered from diffuse Lewy body disease. Further details about the postmortem results and neurochemistry make it clear that although all three cases had numerous cortical Lewy bodies, they also had a sufficient number of plaques, tangles, and amyloid deposits to justify an independent diagnosis of Alzheimer's disease. ${ }^{2}$

This was only one aspect of the heterogeneity of the Alzheimer population and its varied response to tacrine. Equally important was the negative correlation between the presence of dysphasia and improvement when taking the drug. ${ }^{3}$ This variability in response is insufficiently explored by Maltby et al. ${ }^{4}$ Published data suggest that about a third of patients respond to the aminoacridines tacrine and velnacrine. Since only 14 of Maltby et als patients taking the active compound completed the trial, this would at most lead to four or five responders. These numbers would not give the trial sufficient power to elicit such changes. Combined with the relatively low dose used and their failure to quote the largest and most detailed positive trial published so far, ${ }^{5}$ this casts considerable doubt on Maltby et al's stark conclusion that the drug is not clinically useful. The more balanced approach adopted by Byrne and Arie in their editorial far better expresses the complexity of the situation and the questions which now need to be answered.

RAYMOND LEVY

Institute of psychiatry,

Professor of old age psychiatry

London SE5 8AF

1 Byrne EJ, Arie T. Tetrahydroaminoacridine and Alzheimer's disease. BMY 1994;308:868-9. (2 April.)

2 Levy R, Eagger S, Griffiths M, Perry E, Honavar M, Dean A, et al. Lewy bodies and response to tacrine in Alzheimer's disease. Lancer 1994;343:176.

3 Eagger SA, Levy R, Sahakian BJ. Tacrine in Alzheimer's disease. Lancet 1991;337:989-92.

4 Maltby N, Broe GA, Creasey H, Jorm AF, Christensen H, Baltby N, Broe GA, Creasey H, Jorm AF, Christensen $\mathbf{H}$,
Brooks WS. Efficacy of tacrine and lecithin in mild to moderate Brooks WS. Efficacy of tacrine and lecithin in mild to moderate
Alzheimer's disease: double blind trial. BMF 1994;308: 87zheimer.

5 Farlow M, Gracon SI, Hershey LA, Lewis KW, Sadowsky CH, Dolan-Reno JA. A controlled trial of tacrine in Alzheimer's disease. The Tacrine Study Group. YAMA 1992;268:2523-9.

\section{Serum tacrine concentrations too low}

EdrToR,-An important factor in patients' responsiveness to tacrine hydrochloride is the drug concentration achieved during treatment.
Tacrine's complex pharmacokinetics are not mentioned by $\mathrm{E}$ Jane Byrne and Tom Arie in their editorial,' and Nicola Maltby and colleagues discount their importance in their clinical trial. ${ }^{2}$ Failure to take pharmacokinetic factors into account may explain some of the poor response.

Tacrine is extensively metabolised in the liver and has a low systemic bioavailability. Consequently, there is wide interindividual variation in the blood concentration after oral dosing. Serum concentrations provide a more satisfactory prediction of the risk of adverse effects than does the dose alone. Patients who have a serum tacrine concentration greater than $20 \mu \mathrm{g} / \mathrm{h}$ have a sixfold chance of developing cholinergic side effects. ${ }^{3}$ When concentrations of the active metabolite are also taken into account patients who will develop liver enzyme abnormalities can be identified. Using data from the trial of Wilcock $e t a l l^{4}$ we have shown that efficacy also partly depends on the serum drug concentration. Thus patients achieving a serum tacrine concentration greater than $7.5 \mu \mathrm{g} / \mathrm{had}$ a threefold greater probability of showing improvement on a cognitive rating scale $(P<0.05)$. The relevance of measuring the metabolite is illustrated in the same data by a fourfold increase in the chance of improvement when the concentration of the metabolite exceeded $26 \mu \mathrm{g} / \mathrm{l}$ $(\mathrm{P}<0.05)$.

We therefore confirm a therapeutic window for tacrine between about 7.5 and $20 \mu g /$. Further refinement may be possible by considering both the tacrine and the metabolite concentrations together. While Maltby and colleagues state that the mean concentration of tacrine was within this window, the standard deviation of their measurements suggests that many patients had serum concentrations below $7 \mu \mathrm{g} /$. Such patients might have responded at higher concentrations. Indeed, this is suggested by the authors' finding of a weak correlation between blood concentration and performance in memory tests.

Measurement of the serum concentration of tacrine and its metabolite is a useful aid to therapeutic success. The assay is straightforward. Plasma protein binding varies little among patients and is not high enough to disturb the relation between concentration and effect.' In future clinical trials of tacrine measurements of the drug's concentration will identify patients who fail to respond simply because their concentrations are too low. If the drug becomes more generally available monitoring of drug concentrations might make an important contribution to patients' care.

$$
\begin{array}{rr}
\text { CLIVE ROBERTS } & \text { JULLA FORD } \\
\text { Consultant } & \text { Technician } \\
\text { PETRA MÄKELÄ } & \text { CAROL TRUMAN } \\
\text { Student } & \text { Technician }
\end{array}
$$

Department of Medicine,

Southmead Hospital

Bristol BS10 5NB

1 Byme EJ, Arie T. Tetrahydroaminoacridine and Alzheimer's disease. BMF 1994;308:868-9. (2 April.)

2 Maltby N, Broe GA, Creasey H, Jorm AF, Christensen $H_{\text {, }}$ Brooks WS. Efficacy of tacrine and lecithin in mild to moderate Alzheimer's disease. BMF 1994;308:879-83. (2 April.)

3 Ford JM, Truman CA, Wilcock GK, Roberts CJC. Serum concentrations of tacrine hydrochloride predict its adverse effects in Alzheimer's disease. Clin Pharmacol Ther 1993;53: 691-5.

4 Wilcock GK, Surmon DJ, Scott M, Boyle M, Mulligan K, Neubauer KA, et al. An evaluation of the efficacy and safety of tetrahydroaminoacridine (THA) without lecithin in the treatment of Alzheimer's disease. Age Ageing 1993;22:316-24.

5 Makela PM, Truman CA, Ford JM, Keeley P, Roberts CJC. What effect do ageing and disease have on the in vitro plasm protein binding of tacrine hydrochloride (THA)? $\mathrm{Br} f \mathrm{Cl}$ Pharmacol 1994;37:117-8. 